\title{
Lactobacillus GG for Treatment of Acute Childhood Diarrhoea
}

\author{
Sandhya Jain ${ }^{1}$ \\ ${ }^{1}$ Assistant Professor, Department of Pediatrics, World College of Medical Sciences Research and Hospital, Gurawar, Jhajjar-124103.
}

\section{Abstract}

Background: Diarrhoea is a Greek word that's literal meaning is "to flow through like a stream". Diarrhoea is defined as the passage of 3 or more liquid or watery stools in a day with change in consistency and character of the stools. Subjects and Methods: Using this data set, it was calculated that 130 subjects were needed to be enrolled (65 subjects in cases \& 65 subjects in controls) to detect a mean difference in duration of diarrhoea of 24 hours in the both group. Results: Out of 265 children, 130 were found eligible and enrolled in the study, 127 (97.69\%) completed the 7 days follow-up. Two child discontinued the intervention after discharge on day 3 in the intervention group, and three children did not come for follow-up in the control group. Conclusion: Lactobacillus GG in dose of 10 billion cfu/ day for five days given to children aged under five resulted in shortening of the duration of diarrhoea and faster improvement in stool consistency.

Keywords: Acute Childhood Diarrhoea, Follow-up and Lactobacillus GG.

Corresponding Author: Dr Sandhya Jain, Assistant Professor, Department of Pediatrics, World College of Medical Sciences Research and Hospital, Gurawar, Jhajjar-124103

Received: May 2019

Accepted: May 2019

\section{Introduction}

The beneficial effects of probiotics in acute infectious diarrhoea in children so far appear to be moderate, straindependent, dose-dependent and significant mainly in watery diarrhoea and viral gastroenteritis. The effects would be more evident when treatment with probiotics is initiated early in the course of disease. ${ }^{[1]}$ Diarrhoea is a Greek word that's literal meaning is "to flow through like a stream". Diarrhoea is defined as the passage of 3 or more liquid or watery stools in a day with change in consistency and character of the stools. Therefore diarrhoea is a symptom but it is also a sign when the loss of water (stool volume) is more than $15 \mathrm{gm} / \mathrm{kg} /$ day in children $<3$ year and > $200 \mathrm{gm} /$ day in children > 3year of age. ${ }^{[2]}$ Acute diarrhea kills more than 1.5 million children under 5 years of age every year globally, and is the second most common cause of death in this age group. ${ }^{[3]}$ Mostly acute diarrhea in children is of viral origin, and the commonest agent being rotavirus, worldwide. ${ }^{[3]}$ Epidemiological studies have shown that nearly all children under five suffer at least one rotavirus infection, irrespective of the socioeconomic status. ${ }^{[4]}$ Globally, rotavirus causes approximately 6,00,000 deaths in children per year, around $80 \%$ of which occur in developing countries. In India, annually, rotavirus causes an estimated $1,22,000-1,53,000 \quad$ deaths, 4,57,000-8,84,000 hospitalizations and 2 million outpatient visits in children under five. India spends Rs. 2.0-3.4 billion (US\$41- 72 million) annually in medical costs to treat rotavirus diarrhea. ${ }^{[5]}$ Though mortality due to diarrhoea has decreased over the years, it is still unacceptably high. Randomized controlled trials in developed countries have reported benefits of Lactobacillus GG (LGG) and Saccharomyces boulardii in the treatment of acute watery diarrhoea. ${ }^{[6-8]}$ This benefit is seen primarily in rotaviral diarrhoea in infants and young children. ${ }^{[6,7]}$ Similar benefit however, was not seen with other probiotics. ${ }^{[7]}$ Limited information is available on the potential role of Lactobacillus GG in acute diarrhoea in infants and young children living in the developing world, where diarrhoeal aetiology and gut flora are likely to be different. Basu and colleagues have reported beneficial effects of Lactobacillus GG in acute diarrhoea. ${ }^{[9,10]}$ Aim of this present study was to be the efficacy and safety of Lactobacillus GG in the treatment of acute diarrhoea in children.

\section{Subjects and Methods}

This present study was conducted in the Department of Pediatrics at World College of Medical Sciences Research and Hospital, Gurawar, Jhajjar during the period of eight months i.e., from October 2018 to May 2019. Children were eligible for the study if they were aged between 6 months to 5 years and presented with acute diarrhoea to the outpatient department or pediatric emergency services. Diarrhoea was defined as passage of three or more loose stools in the last 24 hours. ${ }^{[11]}$ Children with severe malnutrition (weight for height $<3$ SD of WHO charts), dysentery (presence of visible blood in stools), clinical evidence of co-existing acute systemic illnesses (e.g. meningitis, sepsis, pneumonia) and clinical evidence of chronic disease (e.g. chronic gastrointestinal disease, chronic liver disease, chronic renal disease, nephrotic syndrome) were excluded from the study. Subjects in whom probiotics were used in the preceding 
three weeks or if antibiotics were used for current episode of diarrhoea, were also excluded from the study. The study protocol was approved by the ethical committee of World College of Medical Sciences, Gurawar. Informed written consent was obtained from parents of children enrolled in the study. In a previous study, mean duration of diarrhoea was $58.3 \pm 27.6$ hours in probiotic group and $71.9 \pm 35.8$ hours in placebo group. ${ }^{[12]}$ Using this data set, it was calculated that 130 subjects were needed to be enrolled (65 subjects in cases \& 65 subjects in controls) to detect a mean difference in duration of diarrhoea of 24 hours in the both group, with 90 per cent power and 2- tailed alpha of 0.05 .

\section{Results}

\begin{tabular}{|c|c|c|}
\hline \multicolumn{3}{|c|}{ Figure 1: Shows the follow-up chart. } \\
\hline \multicolumn{3}{|c|}{ Assessed for eligibility $n=265$} \\
\hline & \multicolumn{2}{|c|}{$\begin{array}{l}\text { Excluded } n=135 \\
\text { Did not meet inclusion criteria } n=115 \\
\text { Refused to give consent } n=20\end{array}$} \\
\hline \multicolumn{3}{|l|}{ Randomized n=130 } \\
\hline \multicolumn{3}{|l|}{ Allocation } \\
\hline \multicolumn{2}{|c|}{$\begin{array}{l}\text { Allcated to LGG group } \mathrm{n}=65 \\
\text { Received allocated intervention } \\
\mathrm{n}=65 \\
\text { Did not received allocated } \\
\text { intervention } \mathrm{n}=0\end{array}$} & $\begin{array}{l}\text { Allcated to control group } n=65 \\
\text { Received allocated intervention } n=65 \\
\text { Did not received allocated } \\
\text { intervention } n=0\end{array}$ \\
\hline \multicolumn{3}{|l|}{ Follow up } \\
\hline $\begin{array}{l}\text { Discontinued intervention } \\
\mathrm{n}=2\end{array}$ & \multicolumn{2}{|c|}{ Not contactable $n=3$} \\
\hline Complete follow up $n=65$ & \multicolumn{2}{|c|}{ Complete follow up $\mathrm{n}=65$} \\
\hline Analysed $n=65$ & \multicolumn{2}{|c|}{ Analysed $n=65$} \\
\hline
\end{tabular}

Out of 265 children, 130 were found eligible and enrolled in the study, 127 (97.69\%) completed the 7 days follow-up [Figure 1]. Two child discontinued the intervention after discharge on day 3 in the intervention group, and three children did not come for follow-up in the control group. The baseline characteristics in the two groups were comparable in age, sex and anthropometry. Demographic status and characteristics of acute diarrhea between the two groups was comparable [Table 1].

Table 1: Baseline characteristics in between cases and controls group.

\begin{tabular}{|l|l|l|}
\hline Variables & $\begin{array}{l}\text { Cases (N=65) } \\
\text { LGG } \\
\text { (Mean } \pm \text { SD) }\end{array}$ & $\begin{array}{l}\text { Controls (n=65) } \\
\text { (Mean } \pm \text { SD) }\end{array}$ \\
\hline Age (months) & $14.56 \pm 8.04$ & $16.26 \pm 9.27$ \\
\hline Weight (Kg) & $7.84 \pm 2.65$ & $8.04 \pm 3.02$ \\
\hline Height (cm) & $72.34 \pm 22.1$ & $72.46 \pm 23.01$ \\
\hline $\begin{array}{l}\text { Duration of diarrhoea before } \\
\text { enrolment (days) }\end{array}$ & $2.14 \pm 1.01$ & $2.42 \pm 1.03$ \\
\hline Vomiting [Number (\%)] & $15(23.07 \%)$ & $18(27.69 \%)$ \\
\hline Stool consistency at the time of enrolment \\
\hline Semi-liquid & 14 & 17 \\
\hline Liquid & 51 & 48 \\
\hline $\begin{array}{l}\text { Duration of vomiting before } \\
\text { enrolment (days) }\end{array}$ & $1.56 \pm 0.25$ & $1.86 \pm 0.62$ \\
\hline Hydration status [Number (\%)] & $35(53.84 \%)$ & $37(56.92 \%)$ \\
\hline No dehydration & $15(23.07 \%)$ & $13(20.0 \%)$ \\
\hline Some dehydration & $01(1.53 \%)$ & $5(7.69 \%)$ \\
\hline Severe dehydration & $12 / 65(18.46 \%)$ & $10 / 65(15.38 \%)$ \\
\hline $\begin{array}{l}\text { Rotavirus positive [Number } \\
\text { (\%)] }\end{array}$ &
\end{tabular}

Table 2: Primary outcome variables in between cases and controls group

\begin{tabular}{|c|c|c|c|c|}
\hline Outcome & 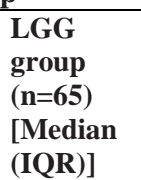 & $\begin{array}{l}\text { Control } \\
\text { group } \\
\text { (n=65) } \\
\text { [Median } \\
\text { (IQR)] }\end{array}$ & $\begin{array}{l}\text { Hazard } \\
\text { ratio } \\
(95 \% \mathrm{CI})\end{array}$ & P value* \\
\hline \multicolumn{5}{|c|}{ Duration of diarrhoea (h) } \\
\hline $\begin{array}{l}\text { All subjects } \\
(\mathrm{n}=130)\end{array}$ & $39(54-72)$ & $51(72-90)$ & $\begin{array}{l}0.274 \\
(0.239, \\
0.451)\end{array}$ & $<0.001$ \\
\hline $\begin{array}{l}\text { Rotavirus } \\
\text { positive } \\
(\mathrm{n}=22)\end{array}$ & $39(54-66)$ & 55 (72-90) & $\begin{array}{l}0.326 \\
(0.232, \\
0.452)^{*}\end{array}$ & $<0.001$ \\
\hline $\begin{array}{l}\text { Rotavirus } \\
\text { negative } \\
(\mathrm{n}=108)\end{array}$ & $39(54-72)$ & $51(72-90)$ & & $<0.001$ \\
\hline \multicolumn{5}{|c|}{ Time to improvement in stool consistency (hours) } \\
\hline $\begin{array}{l}\text { All subjects } \\
(\mathrm{n}=130)\end{array}$ & $24(30-36)$ & $28(36-48)$ & & \\
\hline $\begin{array}{l}\text { Rotavirus } \\
\text { positive } \\
(\mathrm{n}=22)\end{array}$ & $24(30-42)$ & $28(36-48)$ & $\begin{array}{l}0.528 \\
(0.346, \\
0.738)\end{array}$ & $<0.001$ \\
\hline $\begin{array}{l}\text { Rotavirus } \\
\text { negative } \\
(\mathrm{n}=108)\end{array}$ & $24(30-36)$ & $28(36-48)$ & $\begin{array}{l}0.524 \\
(0.374, \\
0.723)^{*}\end{array}$ & $<0.001$ \\
\hline
\end{tabular}

Table 3: Secondary outcome variables in between cases and controls group

\begin{tabular}{|c|c|c|c|c|}
\hline \multicolumn{2}{|l|}{ Outcome } & $\begin{array}{l}\text { LGG } \\
\text { group } \\
(\mathrm{n}=56) \\
(\text { Mean } \pm \\
\text { SD) }\end{array}$ & $\begin{array}{l}\text { Control } \\
\text { group } \\
(\mathrm{n}=57) \\
(\text { Mean } \pm \\
\text { SD) }\end{array}$ & P value \\
\hline \multicolumn{2}{|c|}{$\begin{array}{l}\text { Mean number of stools per } \\
\text { day during diarrhoeal illness }\end{array}$} & $8.74 \pm 2.34$ & $9.86 \pm 3.26$ & $<0.01$ \\
\hline \multicolumn{2}{|c|}{ Duration of vomiting (hours) } & $\begin{array}{ll}13.64 \quad \pm \\
4.52\end{array}$ & $\begin{array}{ll}18.36 & \pm \\
8.16 & \end{array}$ & 0.074 \\
\hline $\begin{array}{l}\text { Duration } \\
\text { (hours) }\end{array}$ & ospital stay & $\begin{array}{ll}76.21 & \pm \\
22.54 & \end{array}$ & $\begin{array}{ll}84.65 & \pm \\
25.41 & \end{array}$ & 0.062 \\
\hline \multirow{3}{*}{$\begin{array}{l}\text { Rotavirus } \\
\text { Positive } \\
(\mathrm{n}=22)\end{array}$} & $\begin{array}{l}\text { Average } \\
\text { number of } \\
\text { stools per } \\
\text { day }\end{array}$ & $\begin{array}{l}8.72 \\
2.34\end{array}$ & $9.41 \pm 3.02$ & 0.32 \\
\hline & $\begin{array}{l}\text { Duration of } \\
\text { vomiting } \\
\text { (hours) }\end{array}$ & $\begin{array}{ll}16.26 & \pm \\
6.02 & \end{array}$ & $20 \pm 8.04$ & 0.27 \\
\hline & $\begin{array}{l}\text { Duration of } \\
\text { hospital stay } \\
\text { (hours) }\end{array}$ & $\begin{array}{ll}78.02 & \pm \\
24.5 & \end{array}$ & $\begin{array}{ll}82.04 & \pm \\
26.35 & \end{array}$ & 0.65 \\
\hline \multirow{3}{*}{$\begin{array}{l}\text { Rotavirus } \\
\text { Negative } \\
(\mathrm{n}=113)\end{array}$} & $\begin{array}{l}\text { Average } \\
\text { number of } \\
\text { stools per } \\
\text { day }\end{array}$ & $\begin{array}{l}8.53 \\
2.64\end{array}$ & $9.21 \pm 3.04$ & 0.76 \\
\hline & $\begin{array}{l}\text { Duration of } \\
\text { vomiting } \\
\text { (hours) }\end{array}$ & $\begin{array}{l}12.24 \\
4.02\end{array}$ & $\begin{array}{l}17.05 \\
8.21\end{array}$ & 0.12 \\
\hline & $\begin{array}{l}\text { Duration of } \\
\text { hospital stay } \\
\text { (hours) }\end{array}$ & $\begin{array}{ll}79.1 & \pm \\
24.65 & \end{array}$ & $\begin{array}{l}98.21 \\
29.02\end{array}$ & 0.04 \\
\hline
\end{tabular}

\section{Primary outcome measures:}

[Table 2] shows the median duration of diarrhoea was significantly $(\mathrm{P}<0.001)$ lesser by about $18 \mathrm{~h}$ in children who received LGG in comparison to control group. There was faster improvement $(\mathrm{P}<0.001)$ in stool consistency by about 6 hours in the LGG group compared to control group. The mean $(95 \% \mathrm{CI})$ difference were $18.76(14.62,22.92)$ and 
$7.80(4.76,10.83)$ hours for duration of diarrhoea and time to improvement in stool consistency, respectively. The benefits on duration of diarrhoea and duration of change in stool consistency were seen both in rotavirus positive and rotavirus negative subjects. The hazard ratios for both durations did not change when rotavirus status was taken as a covariate in cox proportional hazard analysis.

\section{Secondary outcome measures:}

[Table 3] shows the (a) Stool frequency: There was a significant reduction in average number of stool per day in LGG group [mean $(95 \% \mathrm{CI})$ difference of $1.92(0.64,1.76)$ stools per day]. (b) Effect on vomiting: There was no significant reduction in duration of vomiting in the LGG group [mean $(95 \% \mathrm{CI})$ difference of 4.35 hours $(-0.46,9.25)$ hours]. (c) Effect on duration of hospital stay: There was no significant reduction in duration of hospital stay in LGG group [mean $(95 \% \mathrm{CI})$ difference of 12.19 hours (-0.98, 25.27) hours]. No adverse effect was noted in any group. Numbers of vomiting episodes were comparable in the LGG and control groups.

\section{Discussion}

Very few human studies have evaluated the impact of different daily doses of Lactobacillus on faecal recovery over the last decade. This present randomized controlled trial study conducted in World College of Medical Sciences, Gurawar, Jhajjar setting with high background diarrhoeal rates demonstrated that Lactobacillus GG in a dose of 10 billion CFU/ day for five days given to children aged under five during an episode of acute diarrhoea results in shortening of the duration of diarrhoea and faster improvement in stool consistency and frequency. The benefits were seen irrespective of their rotavirus status. A meta-analysis of eight randomized control trials including 988 children of 1 to 36 months, reported that LGG was associated with significant reduction in duration of diarrhoea [weighted mean difference (WMD) of -1.1 days]. Contrary to our study, which did not demonstrate any difference in the outcome in relation to rotavirus status, the meta-analysis reported maximum benefit in diarrhoea due to rotavirus (WMD of -2.1 days). ${ }^{[13]}$ The reason could be that most of the studies included in this meta-analysis were from developed countries, where aetiological strains and gut flora could be different. Basu et al reported from India that Lactobacillus GG given in dose of 60 million cfu twice a day for days 7 had no beneficial effects in children with acute diarrhoea. ${ }^{[9]}$ The absence of benefit in this study could be because of lesser dose used in their study, as another trial by the same group using LGG in dose of 10 billion cfu twice a day for days 7 reported reduction in duration and frequency of diarrhoea, and in hospital stay. They also reported that further increase in dose to 103 billion cfu twice a day did not exhibit any extra benefits. ${ }^{[10]}$ Our study also documented the beneficial effects of LGG in dose of 10 billion cfu/day. The benefits of Lactobacillus GG in diarrhoea could be related to competitive blockage of receptor sites, ${ }^{[14]}$ enhanced immune response by Lactobacilli, ${ }^{[15]}$ transmission of signal(s) from lactobacilli to host that downregulates the secretory and motility defences designed to remove perceived noxious substance, and inactivation of viral particles. ${ }^{[16]}$ Donato et $\mathrm{al}^{[17]}$ have reported that LGG alleviates the effects of proinflammatory cytokines like tumour necrosis factor $\alpha$ (TNF$\alpha)$ and interferon- $\gamma$ on epithelial barrier integrity and inflammation, as CXCL-8 (interleukin-8) and CCL-11 (eotaxin) protein levels were decreased in LGG-inoculated, cytokine-challenged cells. It was mediated, at least in part, through inhibition of TNF- $\alpha$ induced nuclear factor (NF)$\kappa \mathrm{B}$ signalling. Though other species of lactobacilli are commercially available in India, Lactobacillus GG is still not available. The results of this trial do not endorse use of other species of lactobacilli or most other probiotics species, as their effects are not similar and these have not been shown to be as effective in acute diarrhoea in children. ${ }^{[18,19]}$ Potential limitations of this trial include its open labelled nature and lack of placebo control. Moreover, as majority of subjects were not admitted, we relied on information provided by the parents. However, we contacted our patients frequently by repeated communication at short intervals to ensure compliance and to check for outcome. Although rotavirus status was assessed in the stool samples in 112 patients, other aetiologies for acute diarrhoea were not explored and this also was a limitation. We also could not assess the 24 hour stool output. Although we monitored common clinical symptoms such as fever, vomiting, pain abdomen, development of any other new symptoms and any hypersensitivity reaction like skin rashes as potential adverse effects of intervention, we did not monitor for any asymptomatic bacteremia due to Lactobacillus GG.

\section{Conclusion}

In conclusion, the Lactobacillus GG in dose of 10 billion $\mathrm{cfu/}$ day for five days given to children aged under five resulted in shortening of the duration of diarrhoea and faster improvement in stool consistency. The results are applicable for children presenting to hospital in a setting of a developing country and may not be valid for communities. Lactobacillus GG reduced the incidence and duration of diarrhoea, watery or soft stool consistency, and stool frequency. Large scale community based efficacy and effective trials are needed to confirm these results.

\section{References}

1. Szajewska H, Mrukowicz JZ. Use of probiotics in children with acute diarrhea. Paediatr Drugs 2005;7:111-22.

2. WHO, a manual for the treatment of diarrhoea, Programme for control of diarrhoea diseases. WHO/COD/SER/80.2. Rev. 2.1990.

3. Walker CL, Rudan I, Liu L, et al. Global burden of childhood pneumonia and diarrhoea. Lancet 2013;381:1405-16.

4. Wilhelmi I, Rom_an E, S_anchez-Fauquier A. Viruses causing gastroenteritis. Clin Microbiol Infect 2003;9:247-62.

5. Tate JE, Chitambar S, Esposito DH, et al. Disease and economic burden of rotavirus diarrhoea in India. Vaccine 2009;27:F18-24.

6. Allen SJ, Martinez EG, Gregorio GV, Dans LF. Probiotics for 2. 
treating acute infectious diarrhoea. Cochrane Database Syst Rev 2010; $11:$ CD003048.

7. Guandalini S. Probiotics for prevention and treatment of 3. diarrhea. J Clin Gastroenterol 2011; 45 (Suppl): S149-53.

8. Riaz M, Ala4. m S, Malik A, Ali SM. Efficacy and safety of Saccharomyces boulardii in acute childhood diarrhea: a double blind randomised controlled trial. Indian J Pediatr 2012; 79 : 478-82.

9. Basu S, Chatterjee M, Ganguly S, Chandra PK. Efficacy of 5. Lactobacilus rhamnosus GG in acute watery diarrhoea in Indian children: a randomised controlled trial. J Paediatr Child Health 2007; $43: 837-42$.

10. Basu S, Paul DK, Ganguly S, Chatterjee M, Chandra PK. 6. Efficacy of high-dose Lactobacillus rhamnosus GG in controlling acute watery diarrhea in Indian children: a randomized controlled trial. J Clin Gastroenterol 2009; $43: 208-13$.

11. World Health Organization (WHO). The treatment of diarrhoea: 7. a manual for physicians and other senior health workers - 4th rev. Geneva: WHO; 2005; WHO/COD/SER/80.2. Available from: http://whqlibdoc.who.int/publications/2005/9241593180.pdf., accessed on March 29, 2014.

12. Guandalini S, Pensabene L, Zikri MA, Dias JA, Casali 8. LG, Hoekstra $\mathrm{H}$, et al. Lactobacillus GG administered in oral rehydration solution to children with acute diarrhea: a multicenter European trial. J Pediatr Gastroenterol Nutr 2000; $30: 54-60$.

13. Szajewska H, Skorka A, Ruszczynski M, Gieruszczak-Bialek 12. D.
Meta-analysis: Lactobacillus GG treating acute diarrhoea in children. Aliment Pharmacol Ther 2007; $25: 871-81$.

14. Bernet MF, Brassart D, Neeser JR, Servin AL. 13. Lactobacillus acidophilus LA 1 binds to cultured human intestinal cell lines and inhibits cell attachment and cell invasion by enterovirulent bacteria. Gut 1994; $35: 483-9$.

15. Kaila ME, Isolauri E, Soppi E, Virtanen E, Laine S, Arvilommi 14. H. Enhancement of the circulating antibody secreting cell response in human diarrhea by a human Lactobacillus strain. Pediatr Res 1992; 32 : 141-4.

16. Cadieux P, Burton J, Gardiner G, Braunstein I, Bruce AW, 15. Kang CY, et al. Lactobacillus strains and vaginal ecology. JAMA 2002; 287 : 1940-1.

17. Donato K16. A, Gareau MG, Wang YJ, Sherman PM. Lactobacillus rhamnosus GG attenuates interferon-\{gamma\} and tumour necrosis factor-alpha-induced barrier dysfunction and pro-inflammatory signalling. Microbiology 2010; $156:$ 3288-97.

18. Dutta 17. P, Mitra U, Dutta S, Rajendran K, Saha TK, Chatterjee MK. Randomised controlled clinical trial of Lactobacillus sporogenes (Bacillus coagulans), used as probiotic in clinical practice, on acute watery diarrhoea in children. Trop Med Int Health 2011; 16 : 555-61.

19. Khanna 18. V, Alam S, Malik A, Malik A. Efficacy of tyndalized Lactobacillus acidophilus in acute diarrhea. Indian J Pediatr 2005; 72 : 935-8.

Copyright: () the author(s), 2019. It is an open-access article distributed under the terms of the Creative Commons Attribution License (CC BY 4.0), which permits authors to retain ownership of the copyright for their content, and allow anyone to download, reuse, reprint, modify, distribute and/or copy the content as long as the original authors and source are cited.

How to cite this article: Jain S. Lactobacillus GG for Treatment of Acute Childhood Diarrhoea. Asian J. Med. Res. 2019;8(2):PE05-PE08. DOI: dx.doi.org/10.21276/ajmr.2019.8.2.PE2

Source of Support: Nil, Conflict of Interest: None declared.

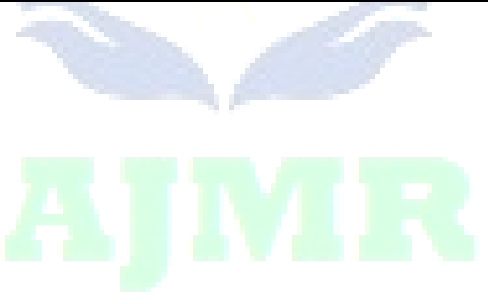

